\title{
MORPHOLOGICAL AND GENETIC CHARACTERIZATION OF PHAEOCYSTIS CORDATA AND P. JAHNII (PRYMNESIOPHYCEAE), TWO NEW SPECIES FROM THE MEDITERRANEAN SEA ${ }^{1}$
}

\author{
Adriana Zingone ${ }^{2}$ \\ Stazione Zoologica A. Dohrn, Villa Comunale, I-80121 Naples, Italy \\ Marie-Josèphe Chrétiennot-Dinet ${ }^{3}$ \\ Observatoire Oceanologique de Banyuls, Université Pierre et Marie Curie I.N.S.U., C.N.R.S, Laboratoire Arago, \\ F-66650 Banyuls-sur-Mer, France \\ Martin Lange $e^{4}$ and Linda Medlin ${ }^{4}$ \\ Alfred Wegener Institute, Am Handelshafen, 12, D-27570 Bremerhaven, Germany
}

Two new Phaeocystis species recently discovered in the Mediterranean Sea are described using light and electron microscopy, and their systematic position is discussed on the basis of an analysis of their nuclearencoded small-subunit ribosomal RNA gene (SSU rRNA) sequences. Phaeocystis cordata Zingone et Chrétiennot-Dinet was observed only as flagellated unicells. Cells are heart shaped, with two flagella of slightly unequal length and a short haptonema. The cell body is covered with two layers of thin scales. The outermost layer scales are oval, with a faint radiating pattern, a raised rim, and a modest central knob. The inner-layer scales are smaller and have a faint radiate pattern and an inflexed rim. Cells swim with their flagella close together, obscuring the haptonema, pushing the cell, and causing it to rotate about its longitudinal axis while moving forward. Phaeocystis jahnii Zingone was isolated as a nonmotile colony. It forms loose aggregates of cells embedded in a mucilaginous, presumably polysaccharide matrix without a definite shape or visible external envelope. The flagellated stage has the features typical of other Phaeocystis species. Cells are rounded in shape and slightly larger than $P$. cordata. The cell body is covered with extremely thin scales of two different sizes with a very faint radiating pattern toward their margin. Swimming behavior is similar to that of $P$. cordata, with the flagella in a posterior position as the cells swim. The SSU rRNA sequence analysis indicated that both species are distinct from other cultivated Phaeocystis species sequenced to date. Regions previously identified as specific for the genus Phaeocystis are not found in $P$. jahnii, and new genus-specific regions have been identified. $P$. cordata is more closely related to the colonial species $P$. globosa, $P$. antarctica, and $P$. pouchetii and has branched prior to the divergence of the warm-water $P$. globosa species complex from the cold-water species $P$. antarctica and $P$. pouchetii. These results are discussed within a framework of

\footnotetext{
${ }^{1}$ Received 9 March 1999. Accepted 6 August 1999.

${ }^{2}$ Author for reprint requests; e-mail zingone@alpha.szn.it.
}

the available data on the evolution of the world's oceans.

Key index words: Mediterranean Sea; Phaeocystis cordata, sp. nov.; Phaeocystis jahnii, sp. nov.; phylogeny; Prymnesiophyceae; SSU rRNA gene analysis; taxonomy; ultrastructure

Abbreviations: DMS, dimethyl sulphide; LM, light microscopy; MPN, most probable number; SDC, serial dilution culture; SSU rRNA, small-subunit ribosomal RNA gene

Phaeocystis Lagerheim is a cosmopolitan genus that includes bloom-forming species that play a key role in many nutrient-rich areas of the world's oceans (Davidson and Marchant 1992, Baumann et al. 1994b). Phaeocystis blooms constitute a recurrent stage in phytoplankton succession in Arctic, Antarctic, and North Sea waters (Lancelot and Rousseau 1994, Lancelot et al. 1998). Large-scale blooms may also have a direct influence on climate because Phaeocystis cells contribute to the release of DMS (Baumann et al. 1994a, Matrai et al. 1995), which influences cloud albedo and possibly the heat flux to the earth's surface (Charlson et al. 1987, Ayers et al. 1997). Blooms directly interfere with human activities by producing net-clogging (Savage 1930, Chang 1983) or dense foams (Lancelot et al. 1987) or by affecting wild-fish taste (Levasseur et al. 1994). In recent years, investigations have focused on Phaeocystis species with the aim of clarifying their physiological characteristics, life-history traits, and potential role in the trophic chain, but many aspects are still to be unequivocally elucidated.

One of the most striking characteristics of Phaeocystis species is their complex life cycle, with different flagellate stages alternating with nonmotile single-celled and colonial stages in a series that is not yet fully understood (Kornmann 1955, Rousseau et al. 1994). This feature, coupled with the notable morphological similarity among Phaeocystis species, has resulted in confused circumscriptions of the different taxa within the genus. Nine Phaeocystis species 
have been validly published, but information on morphology and distinguishing features for most of them is rather superficial (Sournia 1988). The most widely accepted opinion for some years (Sournia 1988, Davidson and Marchant 1992) has been that a single species, $P$. pouchetii (Hariot in Pouchet) Lagerheim, existed, having a broad geographical distribution, and that the only other distinct species in the genus was $P$. scrobiculata Moestrup, described from New Zealand waters (Moestrup 1979). Subsequently, four different species have been recognized on the basis of morphological and ecophysiological traits: $P$. pouchetii, $P$. scrobiculata, $P$. globosa Scherffel, and $P$. antarctica Karsten (Moestrup and Larsen 1992, Baumann et al. 1994b). These species are also distinct in terms of their geographic range. Of the five remaining species, P. fuscescens (Braun) De Toni and $P$. giraudyi (Derbès et Solier) Hamel have definitely been shown not to belong to this genus (Sournia 1988), whereas $P$. brucei Mangin, P. amoeboidea Büttner, and $P$. sphaeroidea Büttner have not been studied since they were described.

Recently, pigment complement, genome size (Vaulot et al. 1994), and genetic similarities (Medlin et al. 1994) have been utilized as valuable characters to substantiate and circumscribe Phaeocystis species. These studies have confirmed that, besides the previously mentioned four valid species, other strains can be separated on the basis of more than one character, and these probably correspond to as yet undescribed species or subspecies.

Unfortunately, progress made in understanding these new species' separation based on genetic and biochemical characteristics has not been supported by adequate morphological discrimination. The shape and internal organization of Phaeocystis colonies has been described for all the species, with the exception of $P$. scrobiculata, for which only flagellate stages are known. However, complete ultrastructural data are not yet available to compare both colonial and flagellated stages of all species. Size and ornamentation pattern of organic scales covering the flagellated cells constitute a reliable character in prymnesiophyte taxonomy but are described only for $P$. globosa (as $P$. pouchetii in Parke et al. 1971) and P. scrobiculata (Moestrup 1979). Complete ultrastructural data are so far available only for the flagellate stages of $P$. globosa (Parke et al. 1971) and the colonial stages of an undescribed Phaeocystis sp. (as P. pouchetii in Chang 1984 but probably $P$. globosa, given its location). Some ultrastructural information is also given for an undescribed species from Natal, South Africa (Pienaar 1991). A distinctive feature described for all Phaeocystis flagellates studied is the release of filaments into a typical "starshaped" structure, composed of a-chitin crystals (Chrétiennot-Dinet et al. 1997).

The purpose of our investigation is to provide formal descriptions of two taxa identified as being distinct by genetic and biochemical data. One of the strains differing from other Phaeocystis in respect to pigments and genome size (Vaulot et al. 1994) was isolated from the Gulf of Naples (Mediterranean Sea). This strain did not form colonies or nonmotile cells. It consisted only of flagellated cells having morphological characters and swimming behavior different from other Phaeocystis species. We provide a morphological description of this species, Phaeocystis cordata Zingone et Chrétiennot Dinet. Another Phaeocystis strain isolated from the same area was initially interpreted as the colonial stage of $P$. cordata but subsequently released swarmers that were different from those of P. cordata. We describe it as Phaeocystis jahnii Zingone and provide information on its distinctive morphological features. A sequence analysis of the SSU rRNA gene was done to assess the position of the two new species within Phaeocystis.

\section{MATERIALS AND METHODS}

Cultures. A unialgal culture of Phaeocystis cordata, Phaeonap1, was established by serial dilution of a seawater sample collected with a Niskin bottle in the Gulf of Naples, at the station MC $\left(40^{\circ} 49^{\prime} \mathrm{N} ; 14^{\circ} 15^{\prime} \mathrm{E}\right)$, at $20 \mathrm{~m}$ on $15 \mathrm{March} 1991$. The culture was isolated and grown in $\mathrm{K}-\mathrm{Si}$ medium (Keller et al. 1987) and kept at $18^{\circ}$ to $25^{\circ} \mathrm{C}$. Irradiance was at $100 \mu \mathrm{mol}$ quanta $\cdot \mathrm{m}^{-2} \cdot \mathrm{s}^{-1} \mathrm{emit}-$ ted from Osram L36W/20 cool-white fluorescent tubes with a 12: 12 h LD (light:dark) cycle. Three more strains were examined for comparison of live material and body scales: Phaeonap2, isolated from the same site at $0 \mathrm{~m}$ on 28 March 1994, and MEDNS2 and MEDNS3, isolated by Nathalie Simon from the northwestern Mediterranean Sea $\left(40^{\circ} 45^{\prime} \mathrm{N} ; 6^{\circ} 7^{\prime} \mathrm{E}, 20\right.$ July 1993 , and $42^{\circ} 51^{\prime} \mathrm{N}$; $3^{\circ} 47^{\prime}$ E, 30 July 1993) and kindly provided by D. Vaulot. Additional information and illustrations were obtained from other mixed dilution cultures and natural samples collected at the station MC (Mare Chiara) on different sampling dates.

Phaeocystis jahnii strains were obtained from a serial dilution culture (SDC) of a natural sample collected in surface waters of the Gulf of Naples (St. MC) on 6 March 1996. This was a mixed culture in which nonmotile cells and mucilaginous colonies of similar cells were noticed along with Phaeocystis-like flagellates and other species. Colonies of four to eight cells were isolated by micropipetting and placed into multiwell plates filled with K-Si medium. After a few days, colonies were transferred to culture tubes with the same medium. Single nonmotile cells were subsequently isolated from these cultures by micropipetting, and two cultures were established, A1 and B5, and grown as previously described. Cultured material of both species was observed and photographed using a Zeiss Axiophot microscope equipped with phase contrast and differential interferential contrast.

Data on the distribution of Phaeocystis spp. were obtained from SDCs (Throndsen 1995) established from seawater samples from the Gulf of Naples and from the Sicily Channel. Cell concentrations were estimated with most probable number (MPN) tables (Throndsen 1995). Other data were derived from formalin-preserved samples collected at station MC.

EM preparations. For TEM observations of scales and filaments, a drop of culture was placed on a TEM grid and fixed using osmium tetroxide $\left(\mathrm{OsO}_{4}\right)$ vapors. The grid was rinsed with distilled water, dried, and then stained with $0.5 \%$ uranyl acetate. Some grids were shadow-cast with gold-palladium at the University of Oslo. For TEM observations of ultrathin sections, cells were fixed in glutaraldehyde and $\mathrm{OsO}_{4}$ as in Zingone et al. (1995). Direct preparations and ultrathin sections were observed and photographed using a Philips TEM 400. Specimens prepared for SEM were fixed in $\mathrm{OsO}_{4}$ and treated as indicated in Zingone et al. (1995). The SEM observations and photographs were made using a Philips 505 SEM. The information provided for the two species is based on about 300 EM micrographs.

Phylogenetic analysis. Two isolates from the Gulf of Naples were selected for the molecular analysis: Phaeonap1 (Phaeocystis corda- 
TABLE 1. GenBank accession number for the small-subunit rRNA sequences analyzed in this study.

\begin{tabular}{ll}
\hline \hline \multicolumn{1}{c}{ Source of sequence material } & \multicolumn{1}{c}{$\begin{array}{c}\text { GenBank } \\
\text { accession } \\
\text { number }\end{array}$} \\
\hline $\begin{array}{l}\text { Rhodomonas salina (Wisl.) Hill et Weth. } \\
\text { Prorocentrum micans Ehr. }\end{array}$ & $\mathrm{X} 54276$ \\
Ochromonas danica Pring. & $\mathrm{M} 14649$ \\
Odontella sinensis (Grev.) Grun. & $\mathrm{M} 32704$ \\
Pavlova gyrans Butch. & Y10570 \\
P. salina (Cart.) Green & $\mathrm{U} 40922$ \\
Phaeocystis jahnii Zing. & $\mathrm{L} 34669$ \\
P. cordata Zing. et Chrét.-Dinet & AF163148 \\
P. antarctica Karst. & AF163147 \\
P. globosa Scherff. & X77480 \\
P. pouchetii (Har.) Lag. & X77476 \\
Pleurochrysis carterae (Braar. et Fag.) Christ. & X77475 \\
Reticulosphaera japonensis Grell & AJ246263 \\
Coccolithus pelagicus (Wall.) Schill. & X90992 \\
Emiliania huxleyi (Loh.) Hay et Mohl. & AJ246261 \\
Prymnesium patelliferum Green, Hibb. et Pien. & L04957 \\
\hline
\end{tabular}

ta) and B5 (Phaeocystis jahnii). Cultures were harvested during logarithmic phase by centrifugation, and total nucleic acid extractions were performed using a 3\% CTAB (hexadecyltrimethylammonium bromide) procedure (Doyle and Doyle 1990).

Total nucleic acid preparations were used as template for the amplification of the $18 \mathrm{~S}$ ribosomal RNA (rRNA) gene. The SSU rRNA gene was amplified in either one or two pieces, using primers previously identified as specific for prymnesiophytes (Medlin et al. 1994, Lange 1997). One of the primers used in the PCR was 5'-biotinylated. Double-stranded PCR products were bound onto streptavidin-coated magnetic beads to obtain single-stranded DNA following the manufacturer's instructions (Dynal, Oslo, Norway). Single-stranded PCR products were used as template in dideoxynucleotide chain termination reactions (Sanger et al. 1977) with internal sequencing primers (Elwood et al. 1985).

The sequences determined from the two Naples strains were aligned with SSU rRNA sequences from other chlorophyll $a+c$ algae, including prymnesiophytes (Medlin et al. 1994, Edvardsen et al. 1999, Medlin, unpubl.) using maximum primary and secondary structural similarity. Phylogenetic analyses were performed on a selection of these taxa (Table 1). Maximum likelihood analyses were performed with the fastDNAml program (ver. 1.0) (Larsen et al. 1993) and with the maximum likelihood option in PAUP version 4.0 (Swofford 1999). For the latter analysis, the Hasegawa Kishino-Yan model was used with a transition/ transversion ratio of 2 with random taxon addition, whereas in the former analysis the Felsenstein model was used with the transition/transversion ratio of 2.0 with random taxon addition. The molecular clock option was not invoked in the PAUP ML analysis, and the rate of evolution at all sites was assumed to follow a gamma distribution with the shape parameter set to 0.5. Distance analyses were performed using the MEGA computer program (Kumar et al. 1993). All ambiguous sites were removed from the data set. Gap sites were removed only in the pairwise comparison. Distances were calculated using the Kimura-2-parameter model (Kimura 1980) and the Jukes-Cantor model (Jukes and Cantor 1969). Distance matrices were converted into trees using the neighbor-joining method (Felsenstein 1993). Maximum parsimony analyses were implemented with the PAUP computer program (Swofford 1993). Introduced gaps were treated as missing data; informative characters were treated as multistate unordered. Unweighted maximum parsimony trees were obtained using the tree-bisection-reconstruction (TBR) branch-swapping option in a branch-and-bound search with random taxon addition. Stability of monophyletic groups was estimated with a bootstrap analysis (500 replicates) of both the maximum parsimony and the distance analysis and 100 replicates for the maximum likelihood analysis.

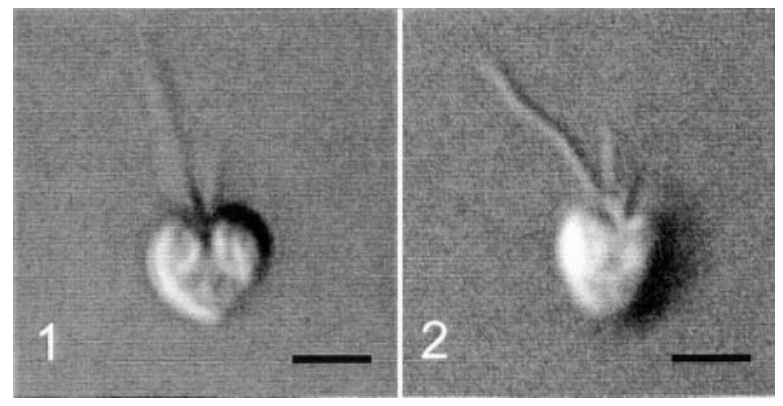

FIGS. 1, 2. Phaeocystis cordata, authentic strain Phaeonap1, LM. FIG. 1. Specimen with the characteristic shape of a heart and the deep invagination at the flagellar emergence region. FIG. 2. Specimen less pointed at the pole opposite to the flagella. Scale bars $=2 \mu \mathrm{m}$.

\section{RESULTS}

Class: Prymnesiophyceae Hibberd

Order: Phaeocystales Medlin

Family: Phaeocystaceae Lagerheim

Genus: Phaeocystis Lagerheim

\section{SPECIES TREATMENT}

Phaeocystis cordata Zingone et Chrétiennot-Dinet, sp. nov.

Cellulae $(3.2 \times 3.8 \mu \mathrm{m})$ cum flagellis cordiformes vel triangulares, dorso-ventraliter compressae, cum satis profunda et ephippiomorpha depressione, circum insertionem flagellorum. Flagella duo subequalia (5.5-7.5 and 4.5-6 $\mu \mathrm{m})$ et breve haptonema $(2.2-2.5 \mu \mathrm{m})$. Chloroplasti duo, aureo-brunnei, lateraliter dispositi. Cellulae stratis dimorphorum squamarum obductae: squamae strati interni et continui ovales et parviores $(0.18 \times 0.13 \mu \mathrm{m})$, margine inflexo, squamae strati externi et continui majores $(0.25$ $\times 0.18 \mu \mathrm{m})$, cum centrata papula, margine erecto. Cellulae extrudens quinque fila delineantes pentagonas stellas in centro. Coloniarius habitus ignotus.

Holotype: Figure 3.

Isotypes: Figures 1-2, 5-9, 11-13, 15, 16, 18, 20. Embedding PhaeonapIIIa, Stazione Zoologica 'Anton Dohrn,' Naples, Italy.

Type locality: Tyrrhenian Sea, station MC, 2 miles offshore Naples $\left(40^{\circ} 49^{\prime} \mathrm{N} ; 14^{\circ} 15^{\prime} \mathrm{E}\right)$.

Authentic strain: Phaeonap1, deposited at the Stazione Zoologica 'Anton Dohrn,' Naples, Italy.

Etymology: The species name cordata ("heartshaped") refers to the shape of heart shown by many cells.

Species description: Light microscopy. Flagellate cells are triangular to heart-shaped, 3 to $3.5 \mu \mathrm{m}$ long and 3 to $4 \mu \mathrm{m}$ wide, with two flagella and a short, noncoiling haptonema emerging from a deep depression (Figs. 1, 2). In lateral view, the cell outline appears oval and thinner $(\sim 2.5 \mu \mathrm{m})$. Two parietal chloroplasts are light golden-brown in color. One flagellum is slightly longer than the other, their respective lengths being 5.5 to $7.5 \mu \mathrm{m}$ and 4.5 to 6 $\mu \mathrm{m}$. The haptonema (Fig. 2), 2.2 to $2.5 \mu \mathrm{m}$ long, is 
not easily seen, especially during swimming. In the anterior part of the cell, one to three disklike bodies are at times present that, in lateral view, appear as short bars. Each disklike body discharges five filaments radiating from a common center (not shown). Small bodies and filaments are commonly seen only in recently established cultures, but filaments were occasionally observed 7 years after isolation.

Cells typically swim with the flagella straight, close one to another, obscuring the haptonema, and pushing the cell. The flagella cause the cells to rotate about their longitudinal axis as they move. Some cells are seen to move differently, with the flagellar pole directed forward. In other cases, cells rotate around one of the flagella for some time. Colonial and nonmotile stages have not been observed.

Electron microscopy. With SEM (Figs. 3-8), cells exhibit a characteristic shape of a heart, more or less pointed at the pole opposite the flagella insertion. The two flagella and the haptonema emerge from a deep, saddle-shaped invagination as seen with LM. This invagination is flanked by the raised shoulders of the cell body (Figs. 3-5, 7). At their insertion point, the flagella are aligned along the dorsoventral axis of the invagination (Fig. 4). The cell surface consists of a continuous layer of nonoverlapping, oval scales with raised rims, showing a smooth central knob (Fig. 8) and giving the cell surface a rough appearance. Scales are shed without any apparent order.

The TEM whole mounts (Fig. 9) show the heartshaped body (2.3 $\mu \mathrm{m}$ long and $3.3 \mu \mathrm{m}$ wide), the flagella (5.6 and $4.9 \mu \mathrm{m}$ long, respectively), and the haptonema (2.2 $\mu \mathrm{m}$ long). Cells joined at the pole opposite to the flagellar insertion were found (Fig. 10) that probably were division stages. Oval scales of two different sizes are visible around the cells (Figs. $9,11)$ or attached to the cell surface in ultrathin sections (Figs. 12, 13). A faint pattern of radiating ribs can be seen on both kinds of scales (Fig. 11). The larger scales $(0.25 \times 0.18 \mu \mathrm{m})$, which form the external investment of the cells (Fig. 13), are the same ones visible with SEM. They have an upraised rim (Fig. 13). The central knob is visible with shadow casting (Fig. 11) and appears as a faint marking in glancing sections (Fig. 12). The inner-layer scales are smaller $(0.18 \times 0.13 \mu \mathrm{m})$ and have an inflexed rim (Fig. 13). As in P. globosa, P. antarctica, and $P$. pouchetii, the five-filament structure ejected by the cells exhibits a five-pointed star at its center (Fig. 14). Scale size and filament pattern did not show significant variability in specimens occasionally observed in whole mounts of natural samples or dilution cultures from the Gulf of Naples. Specimens from cultures MEDNS2 and MEDNS3 showed smaller scales $(0.22 \times 0.17 \mu \mathrm{m}$ and $0.17 \times 0.14 \mu \mathrm{m}$ for larger and smaller scales, respectively).

The TEM sections (Figs. 15-22) show a similar organelle arrangement as described for $P$. globosa (as $P$. pouchetii in Parke et al. 1971). The two chloroplasts (Figs. 15, 17, 18, 20) are sausage to kidney shaped, with a pyrenoid of the immersed type, pointed and having transversing thylakoids (Figs. 17, 18). The nucleus, with a single nucleolus (Fig. 16), is located at the end of the cell opposite the flagella (Figs. 15, 16) and is surrounded by a continuous membrane that includes the two chloroplasts (Fig. 18). Round or elongated sections of mitochondrial profiles are seen at different levels in the cell, from the nuclear to the flagellar pole (Figs. 15, 16, 20), where they occupy part of the two shoulders flanking the flagellar invagination. The Golgi body (Fig. 19 ) is composed of several stacked cisternae that are situated between the two chloroplasts. Scales are seen forming in the distal cisternae (Fig. 19, arrow).

As also seen with SEM, the two flagella and the haptonema emerge from the cell along a line that is transversal to the plane crossing the two chloroplasts (Fig. 20). This is also illustrated in Figure 16 because this section cuts the three appendages but does not cross the chloroplasts. In more proximal transversal sections, the flagellar bases are aligned along a line crossing both chloroplasts (not shown), indicating that torsion of the two basal bodies takes place proceeding from their proximal ends toward the point where the flagella emerge from the cell. The flagellar bases and transition zone (Fig. 21) show the same features illustrated for other members of the Prymnesiophyceae (Birkhead and Pienaar 1994), including a distal and a proximal plate and an electron-dense core in the lumen of the bases. The haptonema has a distal swelling (Fig. 22) similar to that previously described for Phaeocystis globosa (Parke et al. 1971).

Phaeocystis jahnii Zingone, sp. nov.

Cellulae cum flagellis rotundae 3.5-5 $\mu \mathrm{m}$ in diametro, depressione modica ad insertionem flagellorum. Flagella duo inequalia $(8.5-12$ et 5-6.5 $\mu \mathrm{m})$ et brevis haptonema (3-4.5 $\mu \mathrm{m})$. Chloroplasti duo aut quattuor, aureo-brunnei. Stratum circa cellula, squamis tenuissimis et inequalibus in magnitudine compositum. Majores squamae externae et ovales, $0.35 \times 0.28 \mu \mathrm{m}$, sine erecto margine, carinulis levibus et radiantibus ad marginem. Minores squamae interiores, margine inflexo, $0.18 \times 0.14 \mu \mathrm{m}$. Fila desunt. Non mobiles cellulae observatae, solitariae vel glomeratae in duo aut quattuor, circumdatae a matrice polysaccharorum. Adsunt coloniae cum multis cellulis, sine definita forma aut conspicua margine. Coloniariae cellulae cum deminutis flagellis, sed squamis conservatis.

Holotype: Figures 26 to 31.

Isotypes: Figures 23 to 25, Figures 32 to 39. Embedding PhaeoB5/IIa, Stazione Zoologica 'Anton Dohrn,' Naples, Italy.

Type locality: Tyrrhenian Sea, station MC, 2 miles offshore Naples $\left(40^{\circ} 49^{\prime} \mathrm{N} ; 14^{\circ} 15^{\prime} \mathrm{E}\right)$.

Authentic strain: B5, deposited at the Stazione Zoologica 'Anton Dohrn,' Naples, Italy.

Etymology: The species is named in honor of Professor Jahn Throndsen (University of Oslo, Norway), 


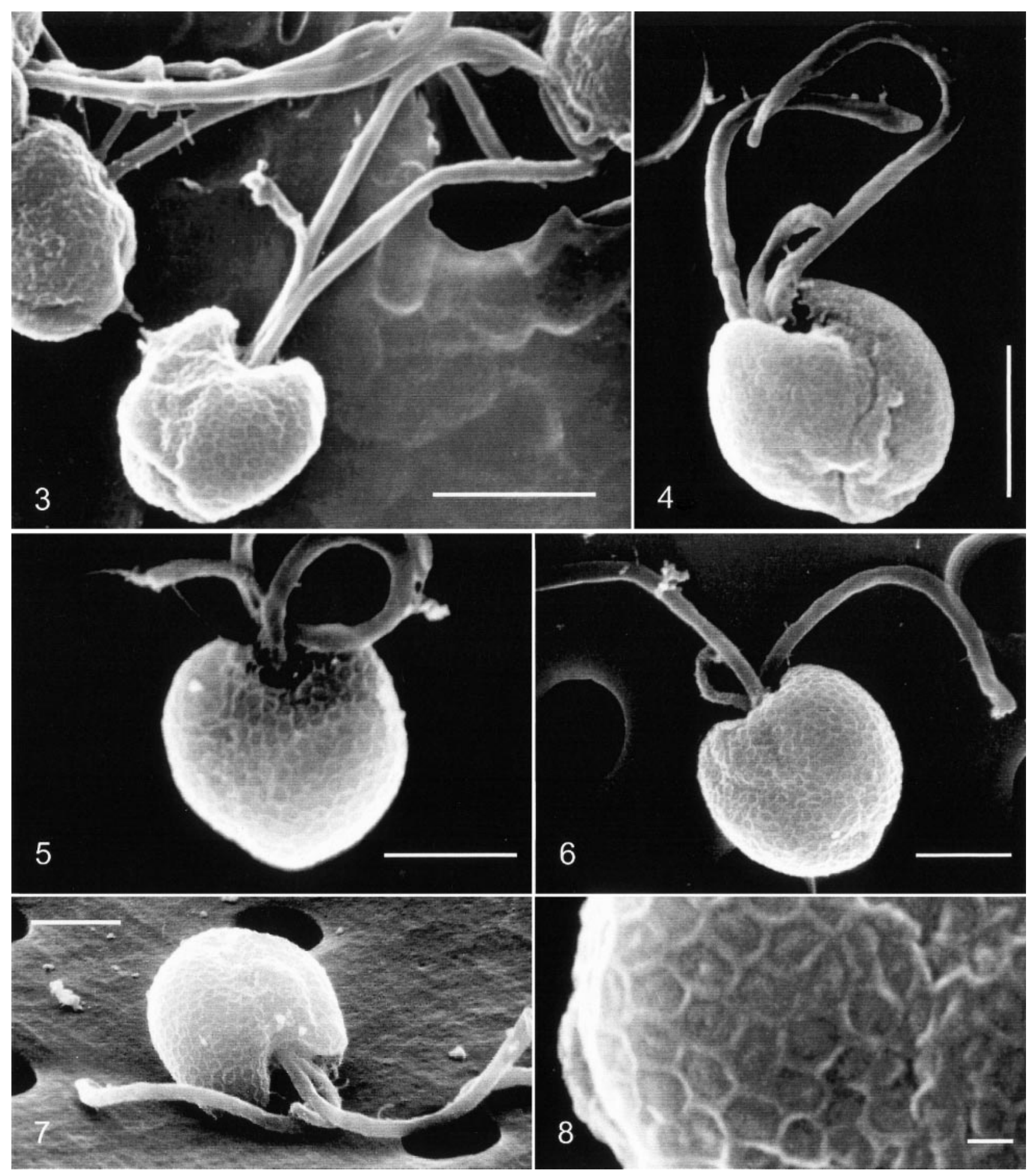

FIGS. 3-8. Phaeocystis cordata, SEM. All cells from the authentic strain, except that in Figure 4. FIG. 3. Whole cell with flagella and haptonema, ventral view. FIG. 4. Whole cell with flagella and haptonema, ventrolateral view. Cell from a mixed dilution culture (St. MC, 8 February 1990). Fig. 5. Whole cell, ventral view. Fig. 6. Whole cell, dorsal view. Fig. 7. Cell seen from the flagellar pole. Fig. 8. Cell surface, showing the scales with raised rims and central knob. Scale bars: Figures $3-7=2 \mu \mathrm{m}$, Figure $8=0.2 \mu \mathrm{m}$.

a famous specialist in flagellate taxonomy and patient teacher of three of the authors.

Species description: Light microscopy. Flagellate cells are rounded, 3.5 to $5 \mu \mathrm{m}$ diameter, with a slight invagination at the flagellar insertion point (Figs. $23,24)$. The two flagella are considerably unequal in size $(8.5-12 \mu \mathrm{m}$ and $5.5-6.5 \mu \mathrm{m}$, respectively), and a short, noncoiling haptonema $(3-4.5 \mu \mathrm{m})$ is 


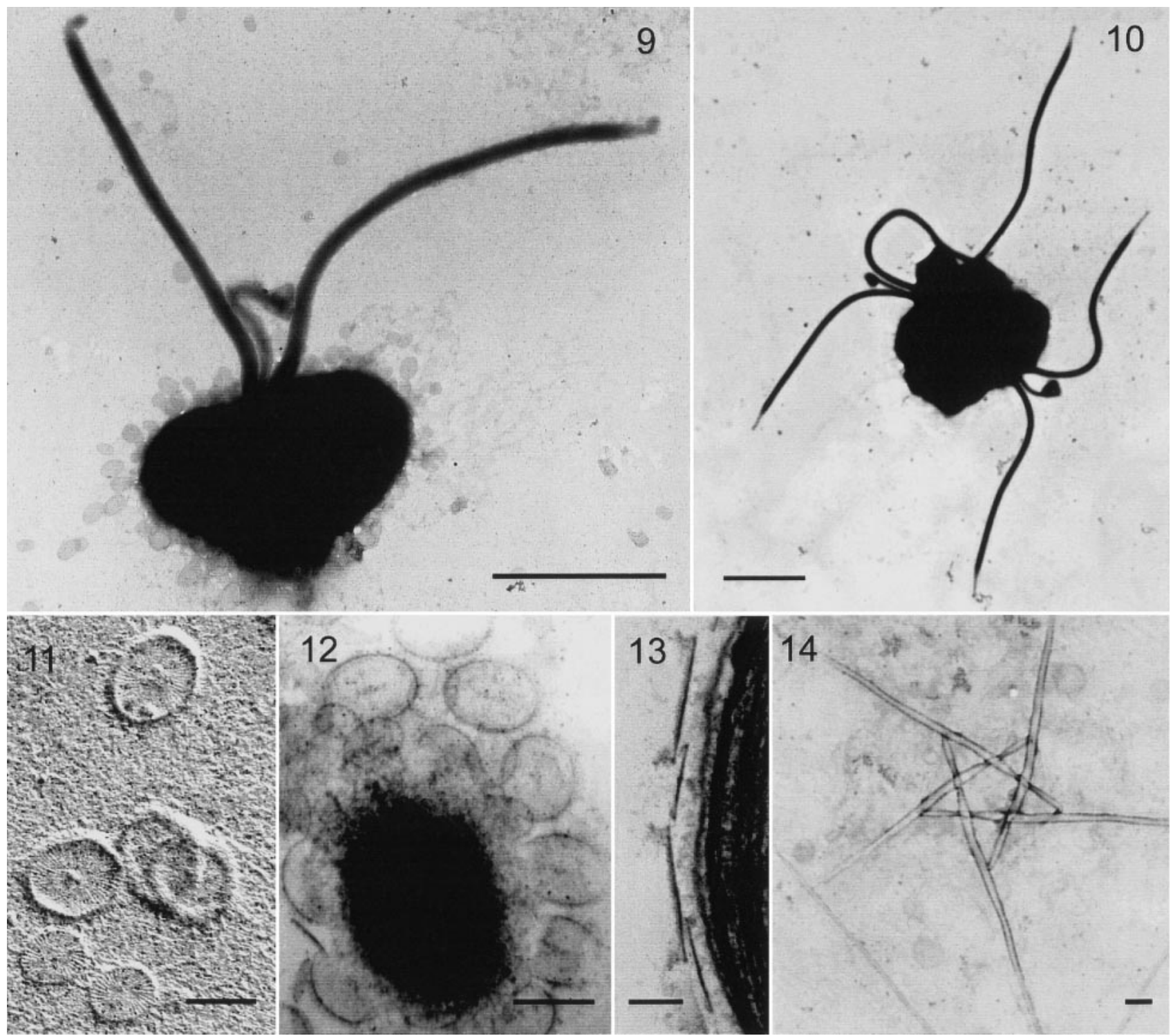

Figs. 9-14. Phaeocystis cordata, all authentic strain, except Figure 14. TEM direct preparations, except Figures 12 and 13. Fig. 9. Whole cell with the two flagella, the haptonema, and scales detached from the cell body. Fig. 10. Division stage. FIG. 11. Shadow-cast direct preparation of scales, the larger ones with a central knob. FIG. 12. Tangential section showing larger scales with a faint marking in the center. FIG. 13. Transverse section of scales, the external ones with upraised rims and the underlying ones with inflexed rims. FIG. 14. Starlike pattern in the center of the five-filament structure, culture MEDNS2. Scale bars: Figures 9 and $10=2 \mu \mathrm{m}$, Figures 11, 12, and $14=0.2 \mu \mathrm{m}$, Figure $13=0.1 \mu \mathrm{m}$.

visible between them. Cells have two to four goldenbrown parietal chloroplasts, and at times show a small, bright yellow-orange body in the space between the chloroplasts (Fig. 24). As in P. cordata, cells usually swim with the flagella pushing the cell, but in some cases the flagellar pole is directed forward. Filaments are not observed.

Colonies (Fig. 25) consist of a variable number of cells embedded in a transparent mucilaginous material that became more visible when stained with Alcian blue. Nonmotile stages are found as single cells separated from the colonies. Colonial and single nonmotile cells are usually larger than the flag- ellated cells, ranging from 6 to $8.5 \mu \mathrm{m}$, and have two to four chloroplasts. A single short appendage, possibly the haptonema, is often visible. Cells are not arranged in a particular order within the colonies. The shape of the colonies is irregular, especially that of the largest ones, and no clear envelope or denser outer layer is visible with or without staining. Often an air bubble is visible in large colonies. Colonial cells form relatively thick layers that stick to the glass culture tube at the air-medium boundary. Small colonies generally have two, four, eight, or 16 cells, implying that cell division within the colony may be synchronous. Some flagellated cells are 


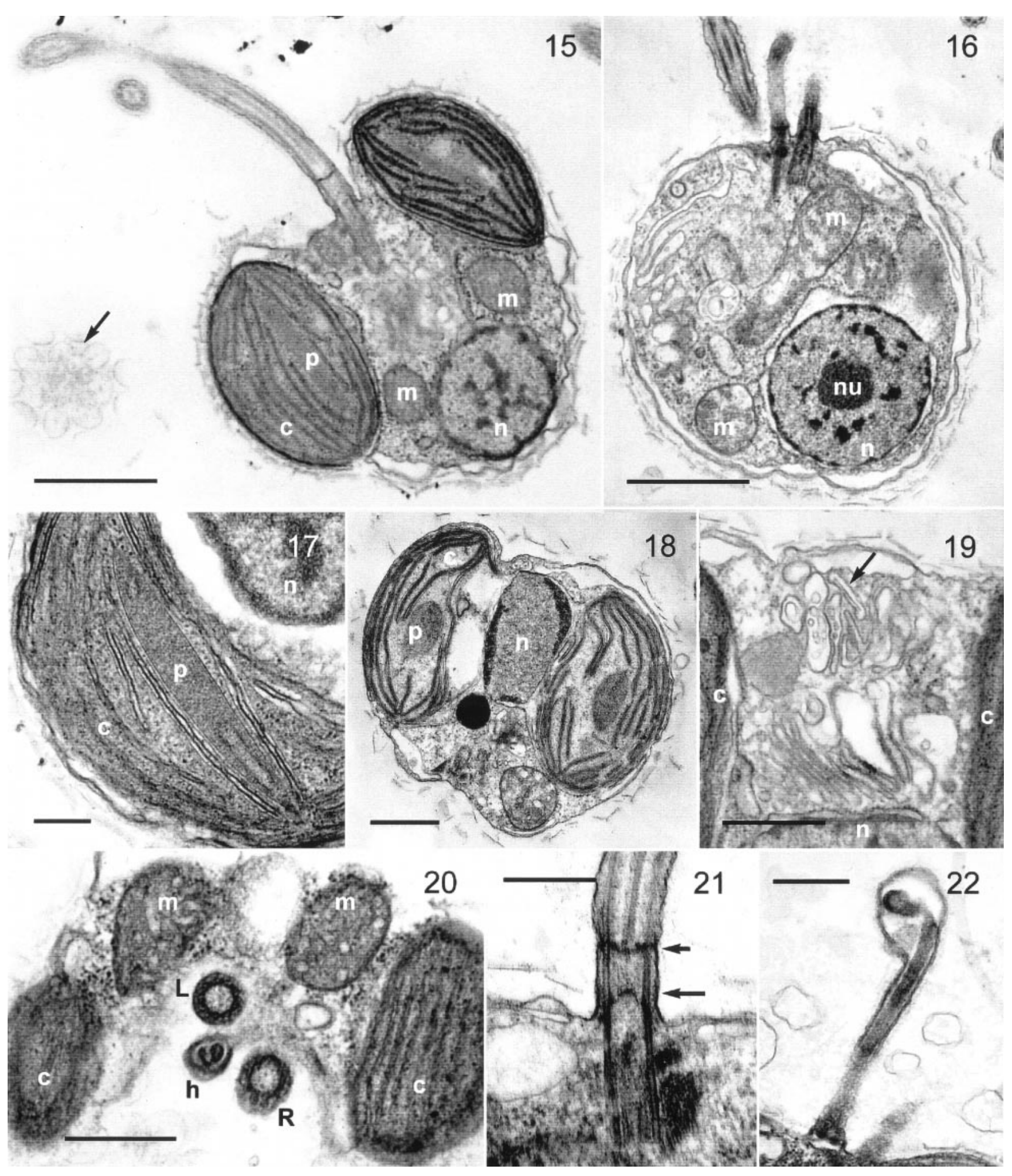

FIGS. 15-22. Phaeocystis cordata, authentic strain, TEM ultrathin sections; $\mathrm{c}=$ chloroplast, $\mathrm{g}=$ Golgi body, $\mathrm{m}=$ mitochondrion, $\mathrm{n}=$ nucleus, $\mathrm{nu}=$ nucleolus, $\mathrm{p}=$ pyrenoid, $\mathrm{L}=$ left flagellum, $\mathrm{R}=$ right flagellum, $\mathrm{h}=$ haptonema, $\mathrm{r}=$ flagellar root. FiG. 15 . Longitudinal section through the chloroplasts, nucleus, and one flagellum. Note the group of scales in glancing view (arrow). FIG. 16. Longitudinal section crossing the flagella and haptonema, the nucleus with the nucleolus but not the chloroplasts. Fig. 17. Detail of the chloroplast, showing the pyrenoid with pointed ends. FIg. 18. Transverse section. Fig. 19. Detail of a longitudinal section showing the Golgi body. A scale is visible in one of the distal vesicles (arrow). FIG. 20. Transverse section through the flagellar pole of the cell. FIG. 21. Longitudinal section of the flagellar bases and the transitional region. Small and large arrows mark the distal and proximal plates, respectively. Fig. 22. Longitudinal section of the haptonema with the swelling end. Scale bars: Figures 15, 16, and $18=1 \mu \mathrm{m}$, Figure $17=0.2 \mu \mathrm{m}$, Figures $19-22=0.5 \mu \mathrm{m}$. 


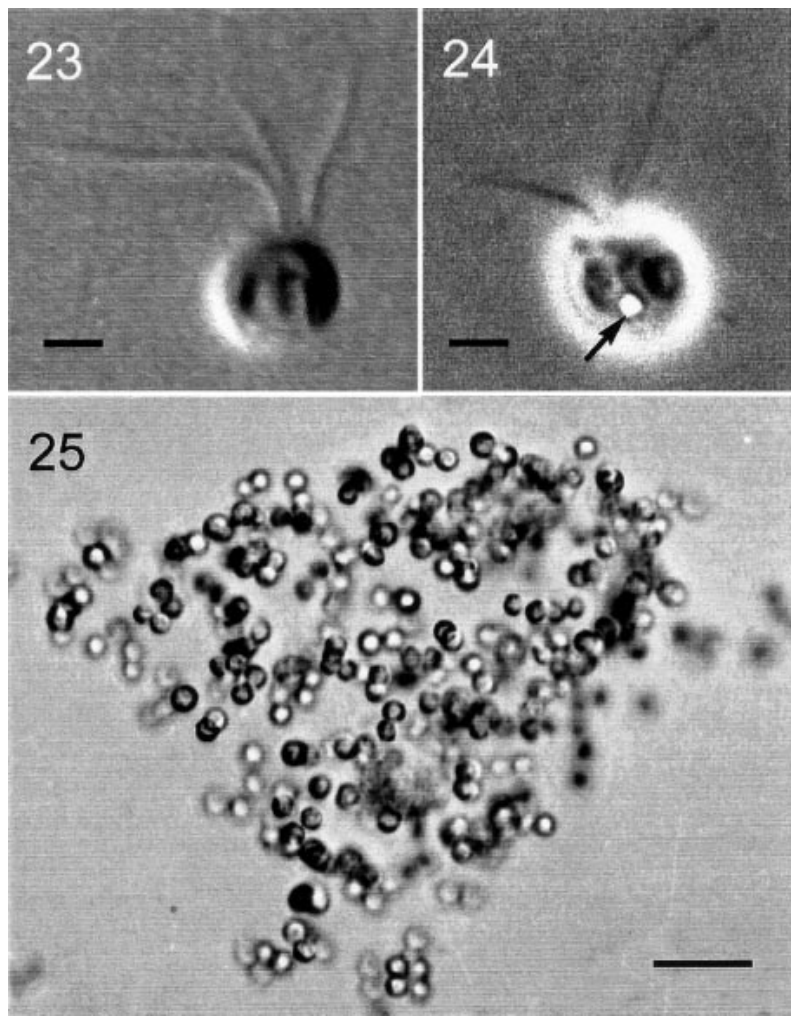

FIGS. 23-25. Phaeocystis jahnii, authentic strain B5, LM. FIG. 23. Flagellate cell with the two unequal flagella and the haptonema. FIG. 24. Flagellate specimen, with the refractive body (arrow) between the chloroplasts . Fig. 25. Colony. Scale bars: Figures 23 and $24=2 \mu \mathrm{m}$, Figure $25=20 \mu \mathrm{m}$.

seen trapped in the matrix, which could either be just forming from nonmotile cells or, conversely, transforming from motile into nonmotile cells.

Electron microscopy. With SEM, flagellates (Figs. 26, 27) show a rounded shape, two unequal flagella and the haptonema, and the slight depression at the region of the flagellar insertion point. The cell surface is slightly rough, but scales were not visible. Nonmotile cells, either colonial (Figs. 28, 30, 31) or single cells (Fig. 29), appear more or less rounded and often show a slightly depressed pit that marks the emergence of the haptonema or an incomplete set of appendages of very reduced length (Figs. 29-31).

TEM whole mounts (Fig. 32) show the cell outline and the markedly unequal length of the two flagella. Scales appear very thin and delicate in whole mounts (Fig. 33) and in ultrathin sections (Fig. 34) and often are difficult to see. They are oval, with a scarcely visible pattern of radiating lines not reaching the central part of the scale. The external layer scales are larger $(0.35 \times 0.28 \mu \mathrm{m})$, lack an upraised rim, and often appear curved (Fig. 34). This is probably an artifact of their extreme thinness because they may appear either flat or convex or concave. The underlying, smaller scales $(0.18 \times 0.14 \mu \mathrm{m})$ are also variously curved and have inflexed rims (Fig. 34).
In ultrathin sections (Figs. 35-43), it is often difficult to distinguish nonmotile and colonial cells from flagellated stages, unless the complete flagellar set or the colonial matrix is clearly shown. In fact, incomplete flagellar sets and scales are often present in colonial cells (Figs. 37-40), and flagellated cells at times show peripheral vesicles (Fig. 36) similar to those found in colonial cells (Fig. 40). The microanatomy of the flagellated stages (Figs. 35-37) is basically the same as described for $P$. cordata. The main differences seen in ultrathin sections are the number of chloroplasts, which in P. jahnii can vary from two to four, and the scales. The orange body, which is at times visible in the light microscope (Fig. 24), may correspond to an electron-dense rounded body visible in some of the sections (Fig. 36). Colonial cells most often show three to four chloroplasts (Figs. 38, 39), a well-developed Golgi body, and a singular elongated mitochondrion. A large number of vesicles are present, more densely packed toward the cell margin. The contents of the vesicles appear to be discharged externally (Fig. 40).

Flagellate stages were rare in embedded material, and no transversal section was found clearly showing the alignment of the three appendages at the point of emergence with respect to the cell body. Sections through the basal bodies (Figs. 41-43) showed differently oriented flagellar roots, here indicated following Birkhead and Pienaar (1994), the central electron-dense core in the flagellar bases (Fig. 42), and the haptonemal base with nine microtubules (Fig. 43). A flagellar root originating from the right basal body was observed (Fig. 43), in a similar position as R6 in Imantonia rotunda Reynolds (Green and Hori 1986).

Distribution. Flagellate cells of $P$. cordata were often found in dilution cultures from the Gulf of Naples from autumn through spring but rarely in summer. The highest MPNs estimated for this species were $10^{5}$ cells $\cdot \mathrm{L}^{-1}$ in February and March 1990 and in April 1996. In formalin-fixed samples, Phaeocystis flagellates were poorly preserved and not easily identifiable. They have been noticed only in recent years, previously being lumped with other unidentified flagellates. In the light microscope, Phaeocystis flagellates often appeared very close to the typical five-rayed stars of filaments, which afforded identification and enumeration. As in dilution cultures, Phaeocystis cells were generally found from September through May in preserved samples from the Gulf of Naples (temperature $=13.5^{\circ}-22^{\circ} \mathrm{C}$; salinity $=37.4-38.2 \mathrm{psu}$ ), and were rarely recorded in summer months. The highest concentrations $\left(<4 \times 10^{5}\right.$ cells $\cdot \mathrm{L}^{-1}$ ) were recorded in April 1996, in agreement with MPN data. We have never seen colonial stages of Phaeocystis in years of observation of both bottle and net samples from the Gulf. It is not possible to exclude that both SDC and counts on fixed samples may include both $P$. cordata and $P$. jahnii cells. However, direct preparations of natural samples and ob- 


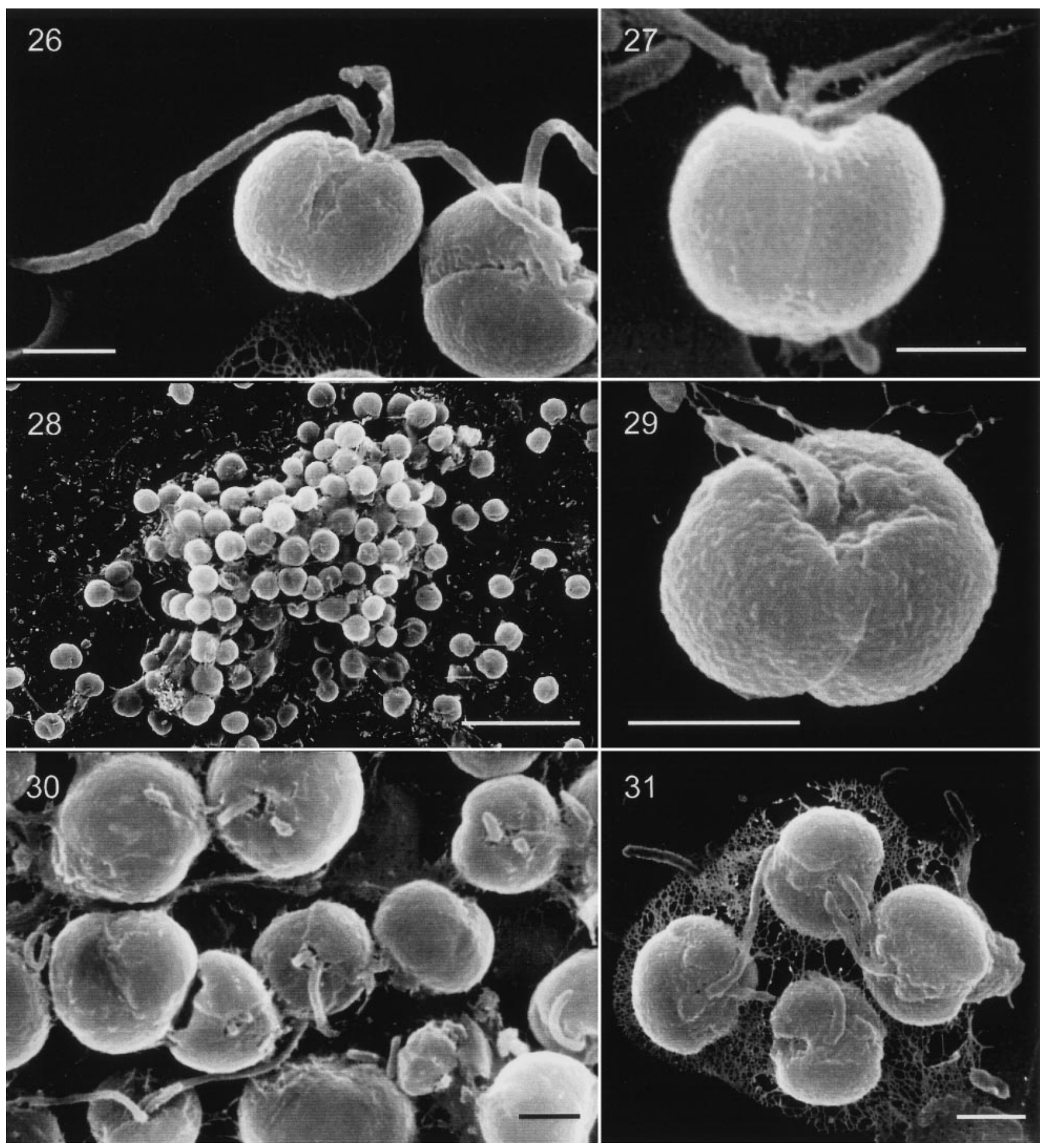

FIGs. 26-31. Phaeocystis jahnii, authentic strain, SEM. FIG. 26. Whole cell with flagella and haptonema. Fig. 27. Whole cell, showing the insertion of the flagella. Fig. 28. Colony. FIG. 29. Noncolonial nonmotile cell, with a single appendage, probably the haptonema. FiG. 30. Detail of Figure 28, showing colonial cells with flagella at different stages of growth. Fig. 31. Four colonial cells in the polysaccharide matrix, with flagella at different stages of growth. Scale bars: Figures 26, 27, 29, 30, and $31=2 \mu \mathrm{m}$, Figure $28=20 \mu \mathrm{m}$.

servations of serial dilution cultures indicate that the species most often counted is $P$. cordata, whereas $P$. jahnii was identified only when it was isolated.

In TEM whole mounts of natural samples from the Gulf of Naples and of dilution cultures from the
Sicily channel, we sometimes recovered filaments arranged in groups of nine, which is a distinguishing character for Phaeocystis scrobiculata. Flagellate cells laying close to these filaments had scales apparently thicker and at times larger $(0.30-0.40 \times 0.21-0.31$ 


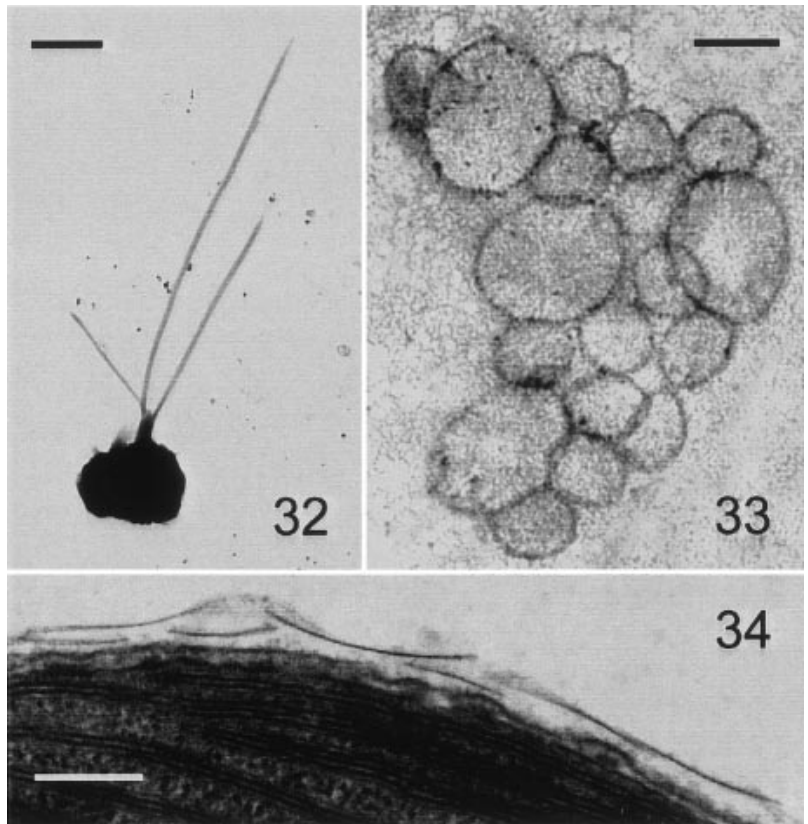

Figs. 32-34. Phaeocystis jahnii, authentic strain, TEM. FIG. 32. Whole cell with the two markedly unequal flagella and haptonema. Fig. 33. Whole mount with scales of two different sizes. Fig. 34. Transverse section of scales, note the inflexed rim of the smaller, underlying scales. Scale bars: Figure $32=2 \mu \mathrm{m}$, Figures 33 and $34=0.2 \mu \mathrm{m}$.

$\mu \mathrm{m})$ than our two new species but smaller than those originally described for $P$. scrobiculata (Table 2).

Molecular analysis. The complete SSU rRNA gene from $P$. cordata and $P$. jahnii was determined. All sequence analyses place the two new taxa close to other Phaeocystis species, with $P$. cordata more closely related to the other three colony-forming Phaeocystis species than $P$. jahnii with strong bootstrap support (Fig. 44). P. cordata and P. jahnii differ from the other three Phaeocystis species from $1.3 \%$ to $3.8 \%$ base substitutions in their SSU rRNA gene, respectively (Table 3 ). By comparison, analyses of multiple isolates of the colonial $P$. antarctica and $P$. globosa reveal one to four base pair differences in the SSU rRNA gene among what is recognized as a single species or a species complex within Phaeocystis.

In an earlier phylogenetic analysis of the colonyforming species of Phaeocystis, a region was identified and tested as a genus level probe for Phaeocystis (Lange et al. 1996). However, with the addition of these two new taxa, this probe is no longer genusspecific as Phaeocystis is presently defined. However, other regions can be used to recognize Phaeocystis as redefined in this study presently defined to include both the colony-forming species and the new unicellular species (Table 4). These regions are presently being tested (Lange and Medlin, unpubl.) for their specificity.

\section{DISCUSSION}

The taxonomy of Prymnesiophyta has been based mainly on morphological characteristics, and different classifications have been proposed in the recent literature (Chrétiennot-Dinet 1990, Cavalier-Smith 1993, Jordan and Green 1994). The need for a common terminology of morphological features in this group has been fulfilled by the "Glossary to the Extant Haptophyta of the World" (Jordan et al. 1995), in which the different taxonomic levels are also discussed. Phaeocystis, with its unusual and complex heteromorphic life cycle, is unique within the Prymnesiophyceae and warrants the creation of the order Phaeocystales (Edvardsen et al. 1999) and the retention of the family Phaeocystaceae, recognized in all earlier systematic schemes (see Jordan et al. 1995). At the genus level, Phaeocystis is easy to identify if it is present in its gelatinous colonial stage. Corymbellus Green, another prymnesiophycean genus producing planktonic colonies, cannot be confused with Phaeocystis because Corymbellus cells are aggregated in motile colonies. The motile unicellular stage of Phaeocystis is much more difficult to recognize in natural samples except when starlike chitinous structures are produced, and cultured material is usually necessary for a reliable identification. Specific identification of either the unicellular or the colonial stage requires a careful examination of the scale covering using SEM and/or TEM or a molecular analysis. Among the morphological characters considered useful, such as the dominant life-cycle stage (motile or nonmotile) present, cell size, flagellar length, and haptonemal behavior, scale patterns rank among the most informative features used to distinguish genera and species of prymnesiophytes.

The flagellated stages of the two new Phaeocystis species found in the Gulf of Naples have basically the same morphological features as the flagellated stages of $P$. globosa, the only species in the genus for which ultrastructural data are available (Parke et al. 1971). Characters shared among the three species include the general arrangement of organelles in the cell, the presence of a short and stiff haptonema between two flagella, and the presence of two layers of slightly different scales. Thus, it was clear that the two new species should be assigned to Phaeocystis. However, each species contained several features distinct from $P$. globosa. The shape of the flagellates was generally unique in $P$. cordata, being easily identified by their compressed, heart-shaped cells. A defining character for P. jahnii was the markedly different lengths of its flagella, which readily distinguishes it from $P$. cordata and $P$. globosa. However, some variability was noted in both cell shape and flagellar length that could prevent a reliable identification of these species based on these characters alone. The size and shape of scales are probably the most typical and reliable morphological feature on which to distinguish our newly described species 

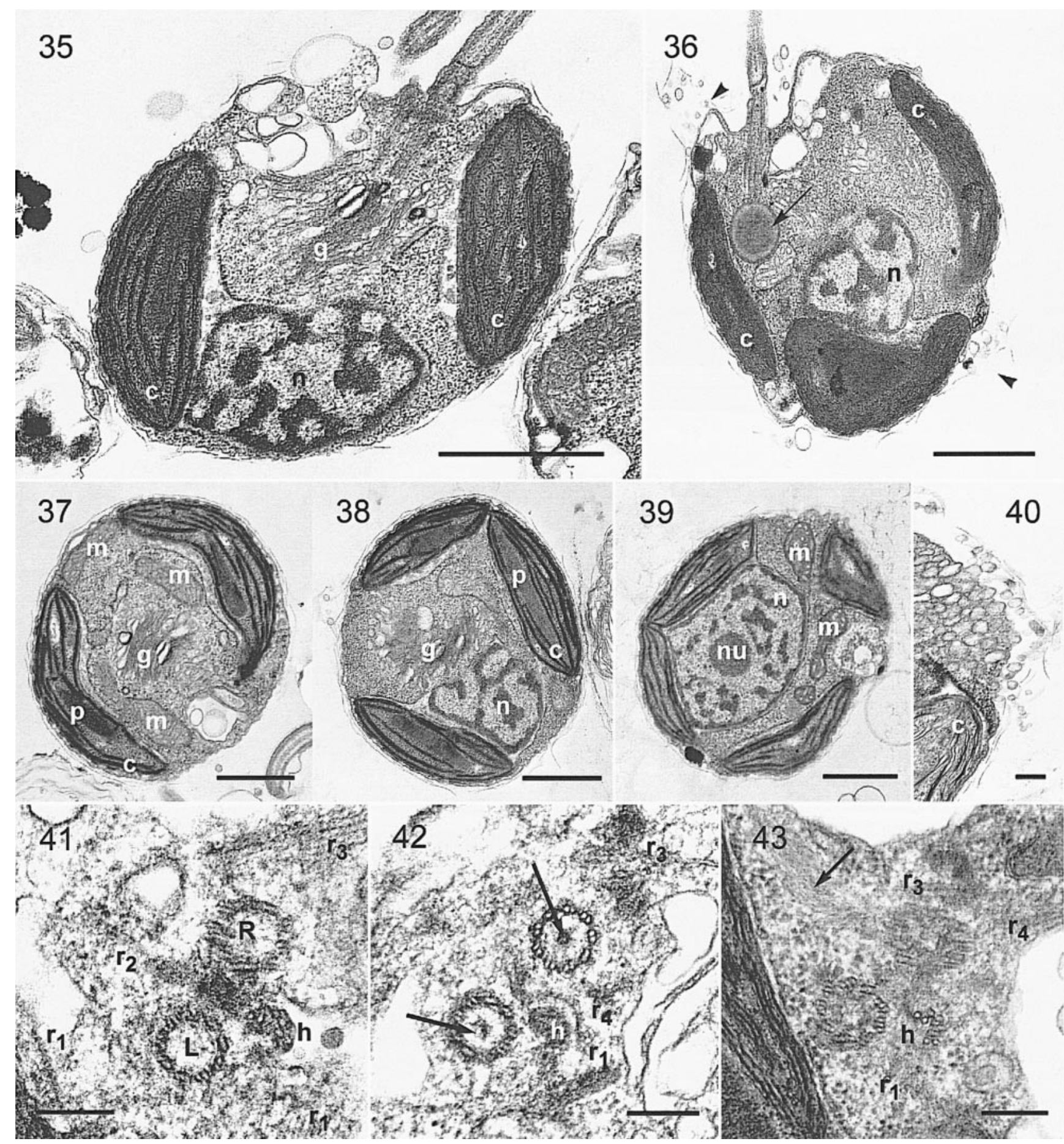

FIGS. 35-43. Phaeocystis jahnii, authentic strain. TEM ultrathin sections. FIG. 35. Whole flagellate cell, longitudinal section. FIG. 36. Longitudinal section of a flagellate cell, showing three chloroplasts. Note the osmiophlic spot (arrow) close to the flagellar base and peripheral vesicles (arrowheads). Fig. 37. Transverse section, showing two chloroplasts with pyrenoids, the Golgi body, and mitochondrion sections. FIG. 38. Cell from a colony, with three chloroplasts, the nucleus, the Golgi body, and the scale investment. FIG. 39. Cell from a colony, with four chloroplasts, the nucleus with the nucleolus, and scales. FIG. 40. Detail of a colonial cell, showing peripheral vesicles below the scale layer. Fig. 41. Section through the flagellar and haptonemal bases, showing flagellar roots. Fig. 42. Section through the flagellar and haptonemal bases, showing flagellar roots. Note the electron-opaque material in the center of the flagellar bases (arrows). FIG. 43. Section through the flagellar and haptonemal bases. Note the flagellar root apparently originating from the right basal body (arrow). Scale bars: Figures 35-39 $=1 \mu \mathrm{m}$, Figures 40-43 $=0.2 \mu \mathrm{m}$. 
TABLE 2. Scale size $(\mu \mathrm{m})$ of motile cells of Phaeocystis.

\begin{tabular}{|c|c|c|c|}
\hline $\begin{array}{l}\text { Phaeocystis } \\
\text { species }\end{array}$ & Large scales & Small scales & Reference \\
\hline P. globosa & $0.18 \times 0.19$ & $0.13 \times 0.10$ & $\begin{array}{l}\text { Parke et al. } \\
\text { (1971) }\end{array}$ \\
\hline P. scrobiculata & $\begin{array}{l}0.60 \times 0.45 \\
0.41 \times 0.30\end{array}$ & $\begin{array}{l}0.21 \times 0.19 \\
0.10 \times 0.10\end{array}$ & $\begin{array}{l}\text { Moestrup (1979) } \\
\text { Hallegraeff } \\
\quad(1983)\end{array}$ \\
\hline P. antarctica & $0.27 \times 0.19$ & $0.18 \times 0.14$ & $\begin{array}{l}\text { Larsen and } \\
\text { Moestrup } \\
\text { (1989) }\end{array}$ \\
\hline P. pouchetii & $0.24 \times 0.25$ & $0.19 \times 0.15$ & $\begin{array}{l}\text { A. Jacobsen, pers. } \\
\text { commun. }\end{array}$ \\
\hline P. cordata & $0.25 \times 0.18$ & $0.18 \times 0.13$ & This paper \\
\hline P. jahnii & $0.35 \times 0.28$ & $0.18 \times 0.14$ & This paper \\
\hline
\end{tabular}

from other Phaeocystis species (Table 2). Whereas inner scales are rather similar, with inflexed rims, those scales constituting the external investment appear to be unique for each species: Those of P. jahnii are distinctively larger than those of all the other Phaeocystis species, except $P$. scrobiculata, and are rimless and extremely thin. The external scales of $P$. cordata have a small central knob and relatively high rims that give the cell surface a rough appearance in SEM. However, to assess definitely the reliability of scale size and shape, as well as of the other features, as taxonomic characters, detailed descriptions of all other Phaeocystis species are required. In addition, observations on more strains are needed to evaluate intraspecific variability for these characters.

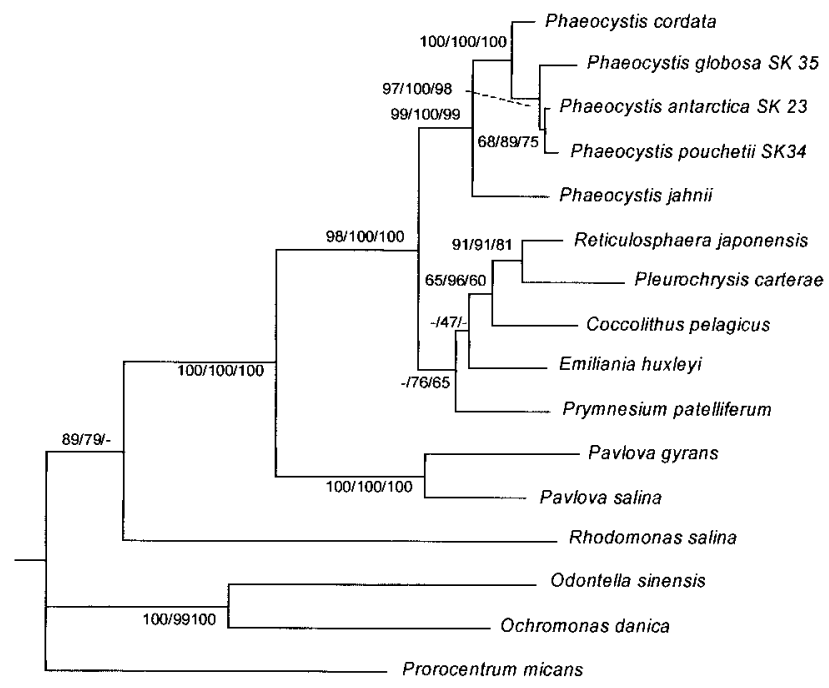

$\underline{1 \%}$

Fig. 44. Maximum likelihood phylogeny of selected prymnesiophytes showing the relationship of unicellular and colonial Phaeocystis species. The tree was inferred from small-subunit ribosomal RNA (SSU rRNA) sequences comparisons of 16 taxa over 1789 nucleotides. Four chlorophyll $a+c$ algae outside the Prymnesiophyceae were used as out-groups. Figures placed above the nodes are bootstrap values based on a maximum likelihood, neighbor-joining, and maximum parsimony analysis (PAUP, tree length $=1273, \mathrm{CI}=0.680, \mathrm{RI}=0.607)$ based on 100,500 , and 500 replicates, respectively.

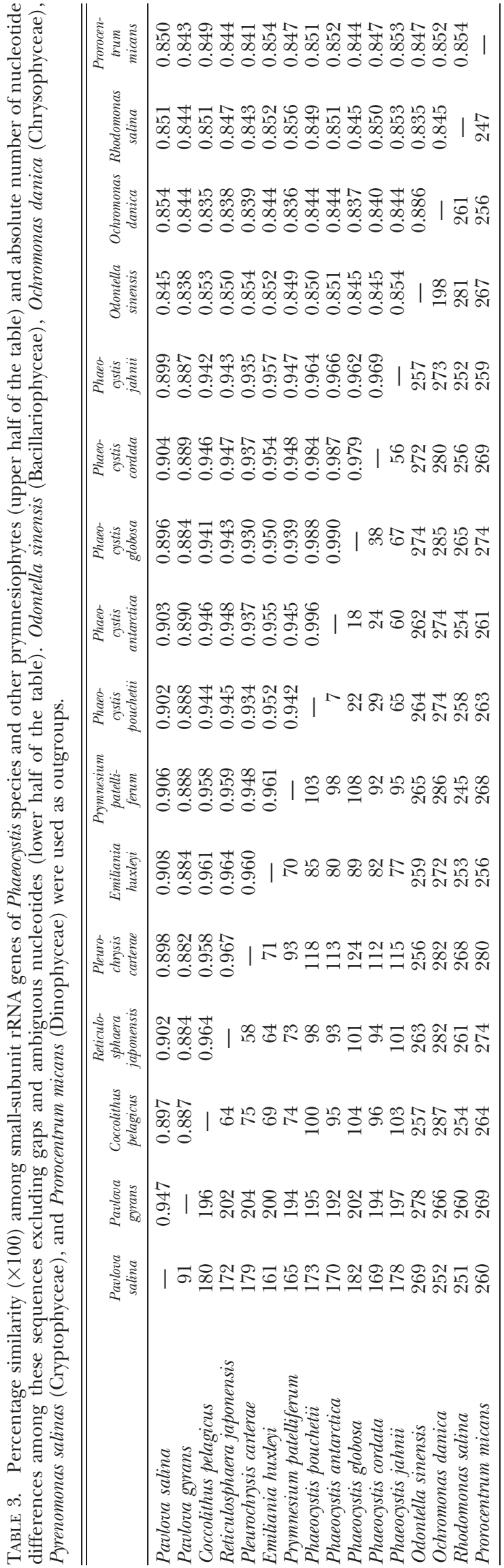


TABLE 4. DNA target positions and their corresponding oligonucleotide probes based on a small-subunit rRNA data set for regions specific for the genus Phaeocystis; positions refer only to Phaeocystis globosa in this data set, but helix numbers are used according to Neefs et al. (1991).

\begin{tabular}{|c|c|c|c|c|}
\hline Probe designation & Target positions & Helix number & & Oligonucleotide sequence \\
\hline PHAEO01 $^{\mathrm{a}}$ & $1488-1505$ & 44 & $\begin{array}{l}\text { Target } \\
\text { Probe }\end{array}$ & $\begin{array}{l}5^{\prime}-\text { ACGAGUCCACCUCGACCG-3' } \\
3^{\prime}-\text { TGCTCAGGTGGAGCTGGC-5' }\end{array}$ \\
\hline PHAEO 02 $^{\text {b }}$ & $647-666$ & E21-1 & $\begin{array}{l}\text { Target } \\
\text { Probe }\end{array}$ & $\begin{array}{l}\text { 5'-CGGGCCGAGCGGUCUGCCGA-3' } \\
3^{\prime}-\text { GCCCGGCTCGCCAGACGGCT-5' }\end{array}$ \\
\hline PHAEO03a & $683-716$ & E21-1 to E21-3 & $\begin{array}{l}\text { Target } \\
\text { Probe }\end{array}$ & $\begin{array}{l}5^{\prime}-\text { GGCGCGGCCUUCUUUCCGGAGACCGCGGCUACUC-3' } \\
3^{\prime}-\text { CCGCGCCGGAAGAAAGGCCTCTGGCGCCGATGAG-5' }\end{array}$ \\
\hline PHAEO04 ${ }^{\text {b }}$ & $485-502$ & 17 & $\begin{array}{l}\text { Target } \\
\text { Probe }\end{array}$ & $\begin{array}{l}5^{\prime}-\text { ACAGGGCUACUUCUAGUC-3' } \\
3^{\prime}-\text { TGTCCCGATGAAGATCAG-5' }\end{array}$ \\
\hline
\end{tabular}

${ }^{a}$ Specific for $P$. globosa, P. pouchetii, P. antarctica, and P. cordata.

${ }^{\text {b }}$ Specific for all known Phaeocystis spp.

A description of the life stages of the heteromorphic life cycle has been provided only for $P$. globosa (Kornmann 1955, Rousseau et al. 1994). Information is restricted to the colony shape in $P$. antarctica and $P$. pouchetii, whereas for P. scrobiculata the colonial stage has never been recorded. In $P$. globosa, three different types of flagellates were identified in the life cycle and classified as swarmers, microzoospores, or macrozoospores. These also have different DNA contents (Casotti, unpubl. data, in Rousseau et al. 1994). In the case of flagellated cells of $P$. cordata, their extremely low DNA content as compared to other Phaeocystis species (Vaulot et al. 1994) suggests that they may be haploid, possibly microzoospores. This hypothesis is supported by the morphological similarity of this new species to the microzoospores described for $P$. globosa (Parke et al. 1971). In the case of $P$. jahnii, no information is yet available on the DNA content of the motile cells observed, and, without a clear picture of the entire life cycle, we are unable to label them with any of the names suggested by Kornmann (1955) for the life-cycle stages. In $P$. jahnii, we also observed nonmotile cells and colonial stages, although features of the latter were somewhat different from classical Phaeocystis colonies in lacking a definite shape and a regular arrangement of cells as well as a visible external envelope. Another unusual finding in $P$. jahnii colonial cells was the presence of a scale investment, not observed in other colonial Phaeocystis species (Chang 1984, M.J.Chrétiennot-Dinet, unpubl. data). The presence of a more or less complete set of appendages in colonial cells is peculiar as well because in P. globosa flagella develop only when colonial cells are released into the external medium (Rousseau et al. 1994). There is circumstantial evidence that colony formation is dependent on environmental parameters (Lancelot et al. 1987, Riegman et al. 1992, Peperzak 1993), although a clear relationship has not yet been traced. Thus, it is impossible to say whether the peculiar features of the colonial stage in P. jahnii are distinctive for the species or attributable to culturing conditions. No information is available on colonial stages in the nat- ural environment because such stages have never been observed in samples from the Gulf of Naples. For the same reason, the absence of colonial stages for $P$. cordata, either in natural samples or in cultures, is not sufficient grounds to exclude the possibility that this species may form colonies because unicellular cultured strains of $P$. globosa exist (Parke et al. 1971). In the latter case, colonies were not produced under a variety of culture conditions, raising the hypothesis that the presence of different mating types may be necessary for colony formation (Vaulot et al. 1994). We were not able to obtain colonies by mixing different strains available in our laboratory but cannot exclude the possibility that all strains belong to the same mating type.

Another feature common to many Phaeocystis species is the formation of filaments extruded by the cells in a characteristic pattern of five- or nine-rayed stars. P. cordata formed these filaments especially during the first months of cultivation, after which they were only occasionally found. As for P. jahnii, we have never observed filaments in culture tubes. It has been suggested that these filaments would be used in the first phases of colony formation as floating anchors, allowing the attachment to Chaetoceros setae and other solid structures and thus favoring stability required for the formation of colonies (Chrétiennot-Dinet 1999). It could also be possible that the release of these strong and resistant structures may function as a defensive mechanism against predation, and this would justify their progressive or total absence in cultures without grazing pressure.

Phaeocystis species from the Gulf of Naples are smaller in size as compared to other congeneric species and are poorly fixed by common preservatives, such as formalin. We only learned to identify and count them as Phaeocystis spp. in fixed material after having repeatedly observed living specimens from SDCs. The five filament stars appear very faint in LM but can often be recognized close to poorly preserved cells; this may be a hint to the identification at least to the generic level. Our data obtained from fixed material and SDCs show that, in the Gulf of Naples, Phaeocystis spp. generally reach a peak in 
spring. Their decline during the summer months cannot be attributed to temperature conditions because the decline generally occurs in May, when water temperatures are about $18^{\circ} \mathrm{C}$, but some cells reappear from September, when water temperatures still exceed $23^{\circ} \mathrm{C}$. It is more likely that thermal stratification, at times enhanced by low-salinity surface waters, plays a major role in limiting their abundance during the summer.

Most information on distribution and geographic range of Phaeocystis species is based only on the presence and abundance of colonial stages. Our findings clearly demonstrate that this genus may be present and reach concentrations up to $4 \times 10^{5}$ cells $\cdot \mathrm{L}^{-1}$ in a place where colonial stages are not recorded. The probability of recognizing the flagellate stages in fixed samples is quite low because of their poor preservation. This means that the possibility of obtaining a more extensive, accurate, and complete assessment of the geographic distribution of this genus, and especially of the distinct species, is not very high, unless collection and identification methods other than those currently used can be applied. A molecular probe recognizing the entire genus would greatly enhance our ability to recognize these species. It is also interesting to note that two new species were easily recovered from the Gulf of $\mathrm{Na}$ ples; this, coupled with the scarce morphological differentiation, suggests that species-level diversity for Phaeocystis may be underestimated.

On the basis of an earlier phylogenetic analysis, it was concluded that Phaeocystis likely originated as a warm-water genus with a global distribution. Using an universal molecular clock for the SSU rRNA gene, Medlin et al. (1994) estimated that the separation of the cold-water and warm-water Phaeocystis species likely occurred no earlier than 50 million years ago (mya) at a time when the world's oceans were thermodynamically more homogeneous than today. The molecular clock for the prymnesiophyte SSU rRNA gene has now been calibrated with the coccolithophorid fossil record (Medlin et al. 1997), and an estimate for the average age of origin of Phaeocystis of $\sim 75$ mya has been calculated. The climate during this time period is generally considered to be very warm (Frakes et al. 1992), consistent with our hypothesis that Phaeocystis originated as a warm-water, cosmopolitan genus. Large continental blocks were breaking up at this time, and the equatorial Tethys Sea could have provided a mechanism through which Phaeocystis cells could achieve a global distribution during more homogeneous oceanic conditions. Divergences between the cold- and warm-water colonial species is now estimated at $\sim 60$ mya, only slightly earlier that that predicted using a universal molecular clock. This estimate is also coincident with major periods of global cooling that produced more normally stratified oceans that may lead to the isolation of populations. Divergences between $P$. antarctica and $P$. pouchetii is estimated at $\sim 30$ mya, consistent with the opening of the Drake passage and the formation of the Antarctic Circumpolar Current (ACC).

It is not known how widely distributed our new Phaeocystis species are, but our hypothesis of the evolutionary history of the genus (Medlin et al. 1994) would suggest that they may be cosmopolitan because they are the first divergences in the genus. Their divergence appears to have occurred at a time (based solely on our molecular clock calculations) when oceanic waters were more homogeneous and taxa are assumed to be more cosmopolitan. Their introduction into the Mediterranean Sea probably has happened from the Atlantic during the last 5 million years because before that the Mediterranean Sea was a desiccated deep-sea basin (Hsü et al. 1977) that has refilled mainly from the Atlantic. Clearly, our knowledge of the biogeography of Phaeocystis flagellate stages is poorly known, and perhaps with the more routine application of molecular probes we have a better chance to map more accurately the distribution of its species.

Unlike Emiliania huxleyi, in which morphological variability is not reflected by comparable diversity at the molecular level because it is such a young taxon (Medlin et al. 1996), it appears that the overall morphological homogeneity within Phaeocystis is contrasted by marked differences in its SSU rRNA gene (Medlin et al. 1994, this paper). Differences of about $2 \%$ in the SSU rRNA gene, such as those recorded between the two new species, are those generally found between different genera (Table 3). Differences among Chrysochromulina spp. are accompanied by high diversity both at the morphological level in terms of scale differences and at the molecular level in terms of divergences of up to $6 \%$, warranting the separation of Chrysochromulina into two or more genera (Medlin, unpubl. data). The apparent uncoupling of molecular and morphological evolution in Phaeocystis suggests that the morphological/life-cycle asset in this genus is especially favorable and advantageous and has been kept with very few changes over considerable evolutionary time. Such conservation has resulted in taxonomic confusion when morphology of the colonial stages is used as the defining specific character. Although the genus is ubiquitous, physiological characteristics of each species are quite well defined, and this could have helped maintain niche segregation and speciation.

We wish to thank Gandi Forlani for his skillful assistance with culture maintenance and EM preparations. Thanks are also due to G. Iamunno for embeddings and ultrathin sections, to G. Gargiulo for the electronic composition of the plates, and to $\mathrm{M}$. Hensh and G. Procaccini for help with the DNA isolation. This research was supported in part by the DFG (SM-22/5-1). This is contribution 1640 from the Alfred-Wegener-Institute.

Ayers, G. P., Cainey, G. M., Gillett, R. W. \& Ivey, J. P. 1997. Atmospheric sulphur and cloud condensation nuclei in marine air in the southern hemisphere. Phil. Trans. R. Soc. Lond. B 352:203-11. 
Baumann, M. E. M., Brandini, F. P. \& Staubes, R. 1994a. The influence of light and temperature on carbon-specific DMS release by cultures of Phaeocystis antarctica and three Antarctic diatoms. Mar. Chem. 45:129-36.

Baumann, M. E. M., Lancelot, C., Brandini, F. P., Sakshaug, E. \& John, D. M. 1994b. The taxonomic identity of the cosmopolitan prymnesiophyte Phaeocystis: a morphological and ecophysiological approach. J. Mar. Syst. 5:5-22.

Birkhead, M. \& Pienaar, R. N. 1994. The flagellar apparatus of Prymnesium nemamethecum (Prymnesiophyceae). Phycologia 33: 311-23.

Cavalier-Smith, T. 1993. Kingdom Protozoa and its 18 phyla. Microbiol. Rev. 57:953-94.

Chang, F. H. 1983. The mucilage-producing Phaeocystis pouchetii (Prymnesiophyceae), cultured from the 1981 "Tasman Bay slime." NZ J. Mar. Freshw. Res. 17:165-8.

- 1984. The ultrastructure of Phaeocystis pouchetii (Prymnesiophyceae) vegetative colonies with special reference to the production of new mucilaginous envelope. NZ J. Mar. Freshw. Res. 18:303-8.

Charlson, R. J., Lovelock, J. E., Andreae, M. O. \& Warren, S. G. 1987. Oceanic phytoplankton, atmospheric sulphur, cloud albedo and climate. Nature 326:655-61

Chrétiennot-Dinet, M.-J. 1990. Chlorarachniophycées, Chlorophycées, Chrysophycées, Cryptophycées, Euglénophycées, Eustigmatophycées, Prasinophycées, Prymnésiophycées, Rhodophycées, Tribophycées. In Sournia, A. [Ed.] Atlas du Phytoplancton Marin, vol. 3. Editions du CNRS, Paris, 261 pp.

1999. An enigma in marine nanoplankton. In Seckbach, J. [Ed.] Enigmatic Microorganisms and Life in Extreme Environments (in press).

Chrétiennot-Dinet, M.-J., Giraud-Guille, M.-M., Vaulot, D., Putaux, J.-L., Saito, Y. \& Chanzy, H. 1997. The chitinous nature of the filaments ejected by Phaeocystis (Prymnesiophyceae). J. Phycol. 33:666-72.

Davidson, A. T. \& Marchant, H. J. 1992. The biology and ecology of Phaeocystis (Prymnesiophyceae). Prog. Phycol. Res. 8:1-45.

Doyle, J. J. \& Doyle, J. L. 1990. Isolation of plant DNA from fresh tissue. Focus 12:13-5.

Edvardsen, B., Eikrem, W., Green, J. C., Andersen, R. A., MoonVan Der Staay, S. Y. \& Medlin, L. K. 1999. Phylogenetic reconstructions of the Haptophyta inferred from $18 \mathrm{~S}$ ribosomal DNA sequences and available morphological data. Phycologia (in press).

Elwood, H. J., Olsen, G. J. \& Sogin, M. L. 1985. The small-subunit ribosomal RNA gene sequences from the hypotrichous ciliates Oxytricha nova and Stylonychia pustulata. Mol. Biol. Evol. 2: 399-410.

Felsenstein, J. 1993. PHYLIP-Phylogeny Inference Package, Version 3.5. Distributed by the author, Department of Genetics, University of Washington, Seattle.

Frakes, L. A., Francis, J. E. \& Syktus, J. J. 1992. Climate Modes of the Phanerozoic. Cambridge University Press, Cambridge, 274 pp.

Green, J. C. \& Hori, T. 1986. The ultrastructure of the flagellar root system of Imantonia rotunda (Prymnesiophyceae). Br. Phycol. J. 21:5-8.

Hallegraeff, G. M. 1983. Scale-bearing and loricate nanoplankton from the East Australian Current. Bot. Mar. 26:493-515.

Hsü, K. J., Garrison, R. E., Montadert, L., Kidd, R. B., Bernoulli, D., Melieres, F., Cita, M. B., Muller, C., Erickson, A. \& Wright, R. 1977. History of the Mediterranean salinity crises. Nature 267:399-403.

Jordan, R. W. \& Green, J. C. 1994. A check-list of the extant Haptophyta of the world. J. Mar. Biol. Assoc. UK 74:149-74.

Jordan, R. W., Kleijne, A., Heimdal, B. R. \& Green, J. C. 1995. A glossary to the extant Haptophyta of the world. J. Mar. Biol. Assoc. UK 75:769-814.

Jukes, T. H. \& Cantor, C. R. 1969. Evolution of protein molecules. In Munro, H. N. [Ed.] Mammalian Protein Metabolism. Academic Press, New York, pp. 21-132.

Keller, M. D., Selvin, R. C., Claus, W. \& Guillard, R. R. L. 1987.
Media for the culture of oceanic ultraphytoplankton. J. Phycol. 23:633-8.

Kimura, M. 1980. A simple method for estimating evolutionary rate of base substitutions through comparative studies of nucleotide sequences. J. Mol. Evol. 16:111-20.

Kornmann, P. V. 1955. Beobachtungen an Phaeocystis-Kulturen. Helgol. Wissenschaftliche Meeresunters. 5:218-33.

Kumar, S., Tamura, K. \& Nei, M. 1993. MEGA: Molecular Evolutionary Genetics Analysis, Version 1.01. Pennsylvania State University, University Park.

Lancelot, C., Billen, G., Sournia, A., Weisse, T., Colijn, F., Veldhuis, M., Davies, A. \& Wassman, P. 1987. Phaeocystis blooms and nutrient enrichment in the continental coastal zones of the North Sea. Ambio 16:38-46.

Lancelot, C., Keller, M. D., Rousseau, V., Smith, W. O. \& Mathot, S. 1998. Autoecology of the marine haptophyte Phaeocystis sp. In Anderson, D. M., Cembella, A. D. \& Hallegraeff, G. M. [Eds.] Physiological Ecology of Harmful Algal Blooms. NATO ASI series, vol. G41, Springer-Verlag, Berlin, pp. 209-24.

Lancelot, C. \& Rousseau, V. 1994. Ecology of Phaeocystis dominated ecosystems: the key role of colony forms. In Green, J. \& Leadbeater, B. S. C. [Eds.] The Haptophyte Algae. Clarendon Press, Oxford, pp. 229-45.

Lange, M. 1997. Phylogeny and taxonomy of the genus Phaeocystis (Prymnesiophyceae). Ph.D. thesis, University of Bremen, 170 pp.

Lange, M., Guillou, L., Vaulot, D., Simon, N., Amann, R. I., Ludwig, W. \& Medlin, L. K. 1996. Identification of the class Prymnesiophyceae and the genus Phaeocystis with ribosomal RNAtargeted nucleic acid probes detected by flow cytometry. $J$. Phycol. 32:858-68.

Larsen, J. \& Moestrup, Ø. 1989. Guide to toxic and potentially toxic marine algae. Ministry of Fisheries, Copenhagen, $61 \mathrm{pp}$.

Larsen, L., Olsen, G. J., Maikak, B. L., McCaughey, M. J., Overbeek, R., Macke, R., Marsch, T. L. \& Woese, C. R. 1993. The ribosomal database project. Nucl. Acids Res. 21(Suppl.): 3021-3.

Levasseur, M., Keller, M. D., Bonneau, E., D'Amours, D. \& Bellows, W. K. 1994. Oceanographic basis of a DMS-related Atlantic cod (Gadus morhua) fishery problem: blackberry feed. Can. J. Fish. Aquat. Sci. 51:881-9.

Matrai, P. A., Vernet, M., Hood, R., Jennings, A., Brody, E. \& Saemundsdottir, S. 1995. Light dependence of carbon and sulfur production by polar clones of the genus Phaeocystis. Mar. Biol. 124:157-67.

Medlin, L. K., Barker, G. L. A., Campbell, L., Green, J. C., Hayes, P. K., Marie, D., Wrieden, S. \& Vaulot, D. 1996. Genetic characterisation of Emiliania huxleyi (Haptophyta). J. Mar. Syst. 9: $13-31$.

Medlin, L. K., Kooistra, W. C. H. F., Potter, D., Saunders, G. W. \& Andersen, R. A. 1997. Phylogenetic realtionships of the "golden algae" and their plastids. In Bhattacharya, D. [Ed.] The Origin of the Algae and Their Plastids. Plant Syst. Evol. 11 (Suppl.): 187-219.

Medlin, L. K., Lange, M. \& Baumann, M. E. M. 1994. Genetic differentiation among three colony-forming species of Phaeocystis: further evidence for the phylogeny of the Prymnesiophyta. Phycologia 33:199-212.

Moestrup, Ø. 1979. Identification by electron microscopy of marine nanoplankton from New Zealand, including the description of four new species. NZ J. Bot. 17:61-95.

Moestrup, Ø. \& Larsen, J. 1992. Potentially toxic phytoplankton. 1. Haptophyceae (Prymnesiophyceae). In Lindley, J. S. [Ed.] ICES Identification Leaflets for Plankton No. 179., ICES, Copenhagen, $11 \mathrm{pp}$

Neefs, J.-M., van de Peer, Y., De Rijk, P., Goris, A. \& De Wachter, R. 1991. Compilation of small ribosomal subunit RNA sequences. Nucl. Acids Res. 19(Suppl.):1987-2015.

Parke, M., Green, J. C. \& Manton, I. 1971. Observations on the fine structure of the zoids of the genus Phaeocystis (Haptophyceae). J. Mar. Biol. Assoc. UK 51:927-41.

Peperzak, L. 1993. Daily irradiance governs growth rate and colony formation of Phaeocystis. J. Plankton Res. 15:809-21. 
Pienaar, R. N. 1991. Thread formation in the motile cells of Phaeocystis. Electron Microsc. Soc. S. Afr. 21:135-6.

Riegman, R., Noordeloos, A. A. M. \& Cadée, G. C. 1992. Phaeocystis bloom and eutrophication of the continental coastal zone of the North Sea. Mar. Biol. 112:479-84.

Rousseau, V., Vaulot, D., Casotti, R., Cariou, V., Lenz, J., Gunkel, J. \& Baumann, M. 1994. The life cycle of Phaeocystis (Prymnesiophyceae): evidence and hypotheses. J. Mar. Syst. 5:2339.

Sanger, F., Nicklen, S. \& Coulsen, A. R. 1977. DNA sequencing with chain termination inhibitors. Proc. Natl. Acad. Sci. USA 74:5463-7.

Savage, R. E. 1930. The influence of Phaeocystis on the migration of the herring. Fish. Invest. Lond. 12:5-14.

Sournia, A. 1988. Phaeocystis (Prymnesiophyceae): how many species? Nova Hedwigia 47:211-7.
Swofford, D. L. 1993. PAUP_Phylogenetic Analysis Using Parsimony, Version 3.1.1. Illinois Natural History Survey, Champaign.

1999. PAUP-Phylogenetic Analysis Using Parsimony, Version 4. Illinois Natural History Survey, Champaign.

Throndsen, J. 1995. Estimating cell numbers. In Hallegraeff, G. M., Anderson, D. M. \& Cembella, A. D. [Eds.] Manual on Harmful Marine Microalgae. IOC Manuals and Guides 33, UNESCO, Paris, pp. 63-80.

Vaulot, D., Birrien, J.-L., Marie, D., Casotti, R., Veldhuis, M. J. W., Kraay, G. W. \& Chrétiennot-Dinet, M.-J. 1994. Morphology, ploidy, pigment composition, and genome size of cultured strains of Phaeocystis (Prymnesiophyceae). J. Phycol. 30:102235 .

Zingone, A., Throndsen, J. \& Forlani, G. 1995. The fine structure of Pyramimonas oltmannsii (Prasinophyceae). Phycologia 34: 241-9. 